\section{R577X OF THE ACTN3 GENE AS PREDICTOR OF PHYSICAL PERFORMANCE IN ULTRAMARATHON RUNNERS}

\author{
R577X DO GENE ACTN3 COMO PREDITOR DE DESEMPENHO FISICO EM ULTRAMARATONISTAS
}

R577X DEL GEN ACTN3 COMO PREDICTOR DE DESEMPEÑO FÍSICO EN ULTRAMARATONISTAS

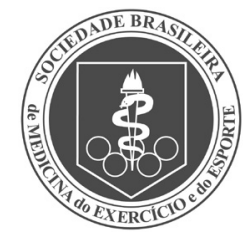

Original Article

ARTIGO ORIGINAL Artículo Original
Marcelo Romanovitch Ribas ${ }^{2}$ (D) (Physical Education Professional) Hiago Augusto Zonatto' (DD (Physical Education Professional) Danieli Isabel Romanovitch Ribas ${ }^{3}$ (ID (Physiotherapist)

Julio Cesar Bassan 1,2 (1D

(Physical Education Professional)

1. Universidade Tecnológica Federal do Paraná (UTFPR),

Postgraduate Program in

Biomedical Engineering (PPGEB),

Curitiba, PR, Brazil.

2. Universidade Tecnológica

Federal do Paraná (UTFPR),

Postgraduate Program in Electrical

Engineering and Industrial

Information Technology (CPGEI),

Curitiba, PR, Brazil.

3. Centro Universitário Autônomo do Brasil (UNIBRASIL), Curitiba, PR, Brazil.

\section{Correspondence:}

Marcelo Romanovitch Ribas Rua Pedro Gusso, 2601, Neoville, Curitiba, PR, Brazil. 81310-900. mromanovitch@yahoo.com.br

\begin{abstract}
Introduction: Genetic factors appear to explain why some athletes perform better in competition and training than their peers. Objective:To determine the occurrence of R577X polymorphism of the ACTN3 gene in mountain runners. Methods: The sample consisted of 19 female mountain runners with a mean age of $41.2 \pm 6.1$ years. Genotyping of R577X polymorphism of the ACTN3 gene was performed by the polymerase chain reaction $(P C R)$ method with DNA extracted from saliva. The genotypic and allelic frequencies of the athletes were evaluated and compared with data from the literature. Hardy-Weinberg equilibrium and Chi-square with Yates correction were used, with a significance level of $p<0.05$. Results: The genotypic distributions did not show any significant differences between the athletes and the control group, with $R R=15.8 \%, R X=57.9 \%, X X=26.3 \%$. In regard to allelic distribution, the nonfunctional allele was higher in the study group than in the control group, with $R=44.7 \%, X=55.3 \%$ for $p=0.0350$. Conclusion: The data revealed a possible relationship between the ACTN3 $X$ allele and athletic performance in Brazilian female mountain runners. Level of evidence Il; Development of diagnostic criteria in consecutive patients (with "gold" reference standard applied).
\end{abstract}

Keywords: Athletes; Actinin/genetics; Athletic performance; Ethnic groups/genetics.

\section{RESUMO}

Introdução: O componente genético parece explicar a melhor adaptação à competição e ao treinamento de alguns atletas com relação a seus pares. Objetivo: Determinar a ocorrência do polimorfismo R577X do gene ACTN3 em atletas corredoras de montanha. Métodos: A amostra foi composta por 19 corredoras de montanha com média de idade de 41,2 $\pm 6,1$ anos. A genotipagem do polimorfismo R577X do gene ACTN3 foi realizada pelo método de reação em cadeia de polimerase (PCR) com DNA extraído da saliva. As frequências genotípica e alélica das atletas foram avaliadas e comparadas com dados da literatura: Equilíbrio de Hardy-Weinberg, Qui-quadrado com correção de Yates, sendo adotado como nível de significância $p<0,05$. Resultados: As distribuições genotípicas $R R=15,8 \%, R X=57,9 \%, X X=26,3 \%$ em comparação com o grupo controle e as atletas da presente investigação, não mostraram diferença significativa. Quanto à distribuição alélica, o alelo não funcional no grupo estudado com relação ao controle foi maior $R=44,7 \%, X=55,3 \%$ para $p=0,0350$. Conclusão: Os dados revelaram uma possivel relação entre o alelo $X$ do ACTN3 e a condição atlética em corredoras de montanha brasileiras. Nível de evidência Il; Desenvolvimento de critérios diagnósticos em pacientes consecutivos (com padrão de referência "ouro" aplicado).

Descritores: Atletas; Actinina/genética; Desempenho atlético; Grupos étnicos/genética.

\section{RESUMEN}

Introducción: El componente genético parece explicar la mejor adaptación a la competición y al entrenamiento de algunos atletas con relación a sus pares. Objetivo: Determinar la ocurrencia del polimorfismo R577X del gen ACTN3 en atletas corredoras de montaña. Métodos: La muestra fue compuesta por 19 corredoras de montaña con promedio de edad de 41,2 66,1 años. El genotipado del polimorfismo R577X del gen ACTN3 fue realizado a través del método de reacción en cadena de polimerasa (PCR), con ADN extraído de la saliva. Las frecuencias genotípica y alélica de las atletas fueron evaluadas y comparadas con datos de la literatura: Equilibrio de Hardy-Weinberg, Chi-cuadrado con corrección de Yates, siendo adoptado como nivel de significancia $p<0,05$. Resultados: Las distribuciones genotípicas $R R=15,8 \%, R X=57,9 \%, X X=26,3 \%$ en comparación con el grupo control y las atletas de la presente investigación, no mostraron diferencia significativa. En referencia a la distribución alélica, el alelo no funcional en el grupo estudiado con relación al control fue mayor $R=44,7 \%, X=55,3 \%$ para $p=0,0350$. Conclusión: Los datos revelaron una posible relación entre el alelo X del ACTN3 y la condición atlética en corredoras de montaña brasileñas. Nivel de Evidencia Il; Desarrollo de criterios diagnósticos en pacientes consecutivos (con estándar de referencia "oro" aplicado).

Descriptores: Atletas; Actinina/genética; Rendimiento atlético; Grupos étnicos/genética. 


\section{INTRODUCTION}

The improvement of physical activity in high-performance sports may be linked to genetic predisposition. ${ }^{1}$ For more than a decade, studies have shown that genetics may explain the different responses and better performance of some athletes in specific modalities when comparing them with their peers. ${ }^{2}$ Moreover, genetic factors can influence up to $50 \%$ the phenotypic characteristics related to performance, training and physical fitness of high-performance athletes. ${ }^{3}$

As many genes and gene areas have already been related to phenotypes of human physical performance, the association between genetics and phenotypic profile can help athletes developing ideal morphophysiological features for certain sports, making them less susceptible to injuries and more prepared for training and competitions. ${ }^{1}$

Thus, the study of genetic polymorphisms can be a prognosis of physical performance. ${ }^{4}$ However, when dealing with studies that consider ethnicity and race of the population studied, we must remember that the phenotypic effects of some polymorphisms may be expressed in multiple ways in different communities. ${ }^{3}$ For Ahmetov et al. ${ }^{1}$ and Yang et al. ${ }^{5}$, genetic polymorphisms associated with sportive success are those that bring benefits, especially related to endurance, sprint and muscle power. In this sense, we highlight R577X polymorphism of the alpha-actinin 3 gene (ACTN3), investigated here because of its association with activities that require muscle strength, sprint, and endurance., 6

Located on chromosome 11q13-q14, this polymorphism is the product of the switch from cytosine to thymine at position 1747 of exon 16, which results in the substitution of arginine (R allele) for a premature stop codon (X allele) at amino acid 577, and thus allowing three genotypes: $R R, R X$ and $X X .{ }^{8}$ The switch of arginine or $R$ allele represents the natural transcription of the a-actinin-3 protein in the skeletal muscle, while the stop codon/ $X$ allele prevents homozygous individuals (genotype XX) from producing a-actinin-3, decreasing the transverse sections area in muscles composed of type 2 fiber predominance, and thus reducing muscle mass, when compared to RR and RX genotypes., ${ }^{8,9}$

However, the non-expression of a-actinin-3 seems to improve aerobic metabolism, increasing the muscle and cardiorespiratory endurance. ${ }^{9,10}$ The relation of ACTN3 with high performance in sports is described by studies that report a greater presence of the $X$ allele in athletes with muscular endurance ${ }^{11,12}$, while those with muscle power and sprint have the $\mathrm{R}$ allele. ${ }^{7,12}$ Considering this, our research aims at better understanding the interaction of ACTN3 R577X polymorphism with the physical performance of female mountain runners in Brazil, since such genetic variation can improve their physical fitness. Moreover, this is an unprecedented analysis of these type of athletes, with the objective of determining the occurrence of $R 577 X$ polymorphism in mountain runners.

\section{MATERIALS AND METHODS}

This is a descriptive transversal study carried out according to Resolution 466/12, during the U/tramaratona dos Perdidos SkyMarathon ${ }^{\circledR}$, a $45-\mathrm{km}$ race with 2,900 m of ascent, relative height of 5,800 m, in the second week of July 2017, in Tijucas do Sul, Paraná, Brazil. The study was also approved by a Research Ethics Committee (CEP) under opinion 1,572,571.

The inclusion criteria were runners with experience of three to four years in mountain races, and in at least two races above $21 \mathrm{~km}$ and one above 42 km, between 2015 and 2016, who trained five to six times a week, one to two hours a day and more than three hours at weekends, and have not reported musculoskeletal diseases. Runners who did not complete the race within a limit time of 11 hours and who did not signed the Informed Consent Form (IFC) were excluded.

\section{Sample}

Of the 34 participants, 15 did not participate in the study because they did not meet the inclusion criteria; thus, the sample consisted of 19 mountain runners, with mean age of $41.2 \pm 6.1$ years.

\section{Procedures}

The runners selected were evaluated in relation to the presence of ACTN3 R577X polymorphism according to the following procedures:

\section{Saliva collection}

Saliva collection was performed in the field, in a specific area to support athletes, and the participants selected for the study sat in a chair with their feet supported. Initially, a 3\% glucose solution was introduced in the participants' mouths, and they swished the product for two minutes. After this, they spat the liquid in a plastic cup. Then the researcher gently rubbed their jugal mucosa with a wooden spatula and washed the spatula in the cup where they spat the solution, and transferred the entire content to a $15 \mathrm{ml}$ Falcon tube.

After collection, the samples were taken in a polystyrene foam box with ice plates to the Laboratory of Genetics and Molecular Biology of a Private Higher Education Institution, in Curitiba/PR, where they were centrifuged at 3000 rpm for 10 minutes. After centrifugation, the supernatant liquid was discarded. We kept the precipitate, added $1300 \mu \mathrm{L}$ of cell extraction buffer (TRIS 10mM, EDTA $5 \mathrm{mM}$, SDS 0.5\%, $\mathrm{pH}=8$ ) and frozen it at $-20^{\circ} \mathrm{C}^{13}$.

\section{DNA extraction}

After defrosting the saliva samples, we added $10 \mu \mathrm{L}$ of Proteinase $\mathrm{K}$ (BioLabs, New England) in each extraction tube and kept them at $65^{\circ} \mathrm{C}$ in water bath overnight.

After taking the samples from the water bath, they were gently agitated and transferred to an $2 \mathrm{~mL}$ Eppendorf (microtube). The researchers added $500 \mu \mathrm{L}$ of ammonium acetate (8mM acetate, $1 \mathrm{mM}$ EDTA) and mixed the solution in a vortex for five minutes. They were then centrifuged at 13,000 rpm for 16 minutes and separated into two $1.5 \mathrm{~mL}$ microtubes ( $900 \mu \mathrm{L}$ in each one), disregarding the pellet deposited at the bottom of the tube and adding $540 \mu \mathrm{L}$ of isopropanol. We gently reversed the tube 20 times to see the DNA.

The content with DNA was centrifuged at 13,000 rpm for seven minutes, the isopropanol was discarded, and we added $1 \mathrm{~mL}$ of $70 \%$ ethanol. The solution was centrifuged again at 13,000rpm for seven minutes (the supernatant was discarded), and kept at room temperature for drying. The DNA was resuspended at approximately $50 \mu \mathrm{L}$ of TE (TRIS 10 mM, 1 mM EDTA, pH=7.76) and kept at room temperature for 24 hours. After this period, the samples were stored for two days in the refrigerator and stored at $-20^{\circ} \mathrm{C}$.

\section{ACTN3 R577X genotyping}

The genotyping of ACTN3 alleles (RR, RX and XX) was performed by the RFLP-PCR technique (polymerase chain reaction through restriction fragment length polymorphism analysis). For this genotyping, we used specific primers (INVITROGEN, Waltham, Massachusetts, USA), 5'-CTGTTGCCTGTGGTAAGTGGG-3' and 5'-TGGTCACAGTATGCAGGAGGG-3'14, and the reactions were performed with a final volume of $10 \mu \mathrm{L}$ in an microtube, containing $1 \mu \mathrm{L}$ (50 ng) of DNA, $0.5 \mu \mathrm{L}$ (10 pmol) of each specific primerr, 0.5 of Taqpolymerase (INVITROGEN, Waltham, Massachusetts, USA) and the required amount of SuperMix (INVITROGEN, Waltham, Massachusetts, USA) to complete the final volume.

The PCRs were carried out in a thermal cycler (Biocycler ${ }^{\circledast}$ ) (New York, USA), with the following amplification program: a) $95^{\circ} \mathrm{C}$ for 5 min.; b) $94^{\circ} \mathrm{C}$ for $30 \mathrm{sec}$; c) $58^{\circ} \mathrm{C}$ for $30 \mathrm{sec}$; d) $72^{\circ} \mathrm{C}$ for $30 \mathrm{sec}$.; e) repeating 30 times the steps $b$ to $d ; f) 72^{\circ} \mathrm{C}$ for 5 min (final extension). 
After amplification, $10 \mu \mathrm{L}$ of the PCR product was submitted to digestion with 10 units of Ddel restriction enzyme (SIGMA) and incubated for 4 hours in water bath at $37^{\circ} \mathrm{C}$.

\section{Electrophoresis in agarose gel}

For analyzing the ACTN3 genotypes, we conducted agarose gel (3\%) electrophoresis, colored with ethidium bromide and visualized with an UV transilluminator.

The R577X alleles were distinguished by the presence (577X) or absence (577R) of a restriction Ddel. enzyme site. ${ }^{14}$ The ACTN3 R577 variant generates fragments of 205 and 86 base pairs, while the ACTN3 577X allele, of 108, 97 and 86 base pairs. ${ }^{5}$ (Figure 1)

\section{Statistical Analysis}

The Pearson's Chi-square test was used to compare the frequencies of genotypes with other studies; when the incidence number of some genotype was less than five, we used the Fisher's exact test. The associations between the alleles frequencies were analyzed by $2 \times 2$ contingency tables, and by the Chi-square test with Yates correction. The Hardy-Weinberg equilibrium was used to verify the distribution of ACTN3 genotypes. The support tool for tests was IBM SPSS Statistics 20 (New York, USA), except for the Hardy-Weinberg Law, which was verified with BioEstat version 5.3 (Belém, Pará, Brazil). All analyses had significance level of $p<0.05$.

\section{RESULTS}

The study included 19 ultramarathoners, with mean age of $41.2 \pm$ 6.1 years, total body mass of $56.9 \pm 7.4 \mathrm{~kg}$, height of $163 \pm 7.3 \mathrm{~cm}$ and fat percentage of $13.73 \pm 1.72 \%$. The distribution of the ACTN3 genotype followed the Hardy-Weinberg equilibrium ( $p=0.45$ ), which shows that the genotypic frequencies found were not different from the values observed in the general population. Therefore, it had no genetic influence on the sample of our study. There were no significant differences in the distribution of ACTN3 genotypes ( $p>0.05$ ) when compared to athletes from other studies. (Tabela 1)

Regarding the allelic and absolute distribution of ACTN3, no significant differences were found $(p=0.51)$, when compared with the studies by Shang et al. ${ }^{15}(p=0.64)$, Belli et al. ${ }^{16}(p=0.25)$, Herbert et al. ${ }^{17}(p=0.23)$, Ben-Zaken etal. ${ }^{12}(p=0.79)$. However, when comparing the results with the research by Coelho et al. ${ }^{18}$, there was a significant difference $(p=0.03)$, showing that the $X$ allele is higher for the study sample. (Table 2)

\section{DISCUSSION}

Regarding the ACTN3 R577X polymorphism in Brazilian athletes, we verified that, until now, there are no studies focused on this interaction in female mountain ultramarathoners, which reveals the unprecedented character of our study.

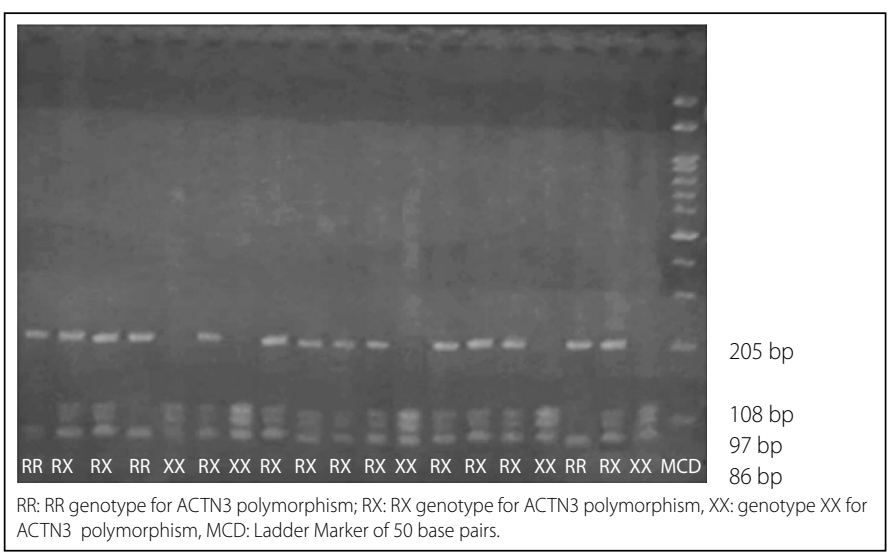

Figure 1.
Table 1. Distribution of genotypic profiles of the 19 ultramarathon athletes in relation to athletes with similar characteristics and control group.

\begin{tabular}{c|c|c|c|c|c}
\hline Research (year) & Sample group (n) & RR (\%) & RX (\%) & XX (\%) & *p-value \\
\hline $\begin{array}{c}\text { Current research } \\
(2018)\end{array}$ & $\begin{array}{c}\text { Mountain } \\
\text { ultramarathoners } \\
(19)\end{array}$ & $3(15.8)$ & $11(57.9)$ & $5(26.3)$ & 0.06 \\
\hline Shang et al. ${ }^{15}$ & Endurance (118) & $22(18.6)$ & $71(60.2)$ & $25(21.2)$ & 0.86 \\
\hline Belli et al. ${ }^{16}$ & $\begin{array}{c}\text { Ultra-endurance } \\
(20)\end{array}$ & $7(35)$ & $9(45)$ & $4(20)$ & 0.38 \\
\hline Herbert et al. ${ }^{17}$ & Marathoners (484) & $141(29.1)$ & $245(50.6)$ & $98(20.2)$ & 0.43 \\
\hline Ben-Zaken et al. ${ }^{12}$ & Endurance (65) & $13(20)$ & $29(44.6)$ & $23(35.4)$ & 0.59 \\
\hline Coelho et al. ${ }^{18}$ & Control (100) & $40(40)$ & $46(46)$ & $14(14)$ & 0.10 \\
\hline${ }^{*}=$ Chi-square with Yates correction. & & & &
\end{tabular}

Table 2. Allelic distribution of the 19 ultramarathoners in relation to athletes with similar characteristics and with the control group.

\begin{tabular}{c|c|c|c|c}
\hline Research (year) & Sample group (n) & $\mathbf{R ~ ( \% )}$ & $\mathbf{X ~ ( \% )}$ & ${ }^{*}$ p-value \\
\hline $\begin{array}{c}\text { Current research } \\
(2018)\end{array}$ & $\begin{array}{c}\text { Mountain } \\
\text { ultra-marathoners (19) }\end{array}$ & $17(44.7)$ & $21(55.3)$ & 0,5164 \\
\hline Shang et al. $^{15}$ & Endurance (118) & $115(48.7)$ & $121(51.3)$ & 0,6476 \\
\hline Belli et al. $^{16}$ & Ultra-endurance (20) & $23(57.5)$ & $17(42.5)$ & 0.2596 \\
\hline Herbert et al. $^{17}$ & Marathoners (484) & $527(54.4)$ & $441(45.6)$ & 0,2389 \\
\hline Ben-Zaken et al. $^{12}$ & Endurance (65) & $55(42.3)$ & $75(57.7)$ & 0,7901 \\
\hline Coelho et al. ${ }^{18}$ & Control (100) & $126(63)$ & $74(37)$ & $0,0350^{*}$ \\
\hline${ }^{*}=$ Chi-square with Yates correction & & &
\end{tabular}

The results obtained in terms of absolute and relative ACTN3 genotypic frequency showed that, when compared with studies conducted with endurance athletes from China ${ }^{15}$ and Israel, ${ }_{1}^{12}$ ultra-endurance runners from Brazil, ${ }_{16}^{16}$ European marathoners ${ }^{17}$ and with the Brazilian population in general, ${ }^{18}$ there is no statistically significant difference.

Although the literature ${ }^{12,19,20,15}$ evidences the genotypic association of ACTN3 with athletic performance in high-performance modalities, this study did not find any connection of genotype with athletic performance, corroborating the studies conducted by Ahmetov et al., ${ }^{4}$ Lucia et al. ${ }^{21}$, and Muniesa, ${ }^{22}$ who researched the ACTN3 association and the athletic performance of elite Russian rowing athletes, elite European cyclists and European runners, respectively.

On the other hand, studies conducted by Ben-Zaken et al., ${ }^{12}$ Druzhevskaya et al. ${ }^{19}$ Gómez-Gallego et al. ${ }^{20}$ showed a relationship between genotype and performance. Ben-Zaken et al. ${ }^{12}$ showed evidence of the relationship between genotype $X X$ and the fitness of endurance athletes. Druzhevskaya et al. ${ }^{19}$ found that $3.4 \%$ of elite athletes focused on muscle strength expressed genotype XX, and Gómez-Gallego et al. ${ }^{20}$ observed that RR and RX genotypes are related to the peak power of endurance cyclists.

When comparing the allelic distribution with the control group, ${ }^{18}$ we noticed that our sample has a frequency of the higher X allele $(55.3 \%$ vs $37 \%$ ), which is in agreement with Shang et al. ${ }^{15}$ According to these authors, women have higher frequency of genotype XX (21.2\% vs $15.8 \%)$, as well as of the $X$ allele (51.3\% vs $41.1 \%)$, when compared to the control group; but the same is not valid for men, which suggests that the non-functional allele of the gene may provide advantages for women in endurance tests.

Most long-distance athletes have a higher distribution of the $X$ allele, $^{12}$ which influences muscle function in fast fibers, directing muscle metabolism to an aerobic pathway, which results in improved endurance performance. $^{9,10}$

Although Yvert et al. ${ }^{23}$ point out the R allele presence in elite endurance athletes, and other inconclusive studies have not linked physical performance with ACTN3 R577X polymorphism in athletes with high strength and power ${ }^{20}$ and muscle endurance, ${ }^{6}$ some studies ${ }^{11,12}$ suggest 
that the non-functional allele $(X)$ is present in individuals focused on sprint/power modalities, while the mutant allele $(R)$ is more present in muscle endurance athletes. ${ }^{11,24}$

\section{CONCLUSION}

This study was the first to analyze ACTN3 in Brazilian female ultramarathoners and found that $84.2 \%$ of the sample had the non-functional $X$ allele, distributed in heterozygous and/or homozygous pattern, which supports the hypothesis that the non-functional allele of ACTN3 is associated with a good performance in high-level sports in Brazilian women who are mountain ultramarathoners.

All authors declare no potential conflict of interest related to this article

AUTHORS' CONTRIBUTIONS: Each author made significant individual contributions to this manuscript. HAZ, MRR, DIRR and JCB: accompanied the data collection, guided the construction of the study and assisted in the statistical analysis and revision. All authors made intellectual contributions to the study.

\section{REFERENCES}

1. Ahmetov II, Egorova ES, Gabdrakhmanova LJ, Fetodovskaya ON. Genes and Athletic Performance: an Update. Med Sport Sci. 2016;61:41-54.

2. Pitsiladis $Y$, Wang G, Wolfarth B, Scott R, Fuku N, Mikami E, et al. Genomics of elite sporting performance: what little we know and necessary advances. Br J Sports Med. 2013;47(9):550-5.

3. Eynon N, Ruiz JR, Oliveira J, Duarte JA, Birk R, Lucia A. Genes and elite athletes: a roadmap for future research. J Physiol. 2011;589(Pt 13):3063-70

4. Ahmetov II, Popov VD, Astratenkova VI, Druzhevskaya MA, Missina SS, Vinogradova LO, et al. The use of molecular gentic methods for prognois of aerobic and anaerobic performance in athletes. Hum Physiol. 2008;34(3):338-42.

5. Yang N, Macarthur DG, Gulbin JP, Hahn AG, Beggs AH, Easteal S, et al. ACTN3 genotype is associated with human elite athletic performance. Am J Hum Genet. 2003;73(3):627-31.

6. Gineviciene V, Jakaitiene A, Aksenov MO, Aksenova AV, Druzhevskaya AM, Astratenkova IV, et al. Association analysis of ACE, ACTN3 and PPARGC1A gene polymorphisms in two cohorts of European strength and power athletes. Biol Sport. 2016;33(3):199-06.

7. Ma F, Yang Y, Li X, Zhou F, Gao C, Li M, et al. The Association of Sport Performance with ACE and ACTN3 Genetic Polymorphisms: A Systematic Review and Meta-Analysis. PLoS One. 2013;8(1):e54685.

8. Vincent B, De Bock K, Ramaekers M, Van den Eede E, Van Leemputte M, Hespel P, et al. ACTN3 (R577X) genotype is associated with fiber type distribution. Phys Genomics. 2007;32(1):58-63.

9. MacArthur DG, Seto JT, Chan S, Quinlan KG, Raftery JM, Turner N, et al. An Actn3 knockout mouse provides mechanistic insights into the association between alpha-actinin-3 deficiency and human athletic performance. Hum Mol Genet. 2008;17(8):1076-6.

10. MacArthur DG, Seto JT, Raftery JM, Quinlan KG, Huttley GA, Hook JW, et al. Loss of ACTN3 gene function alters mouse muscle metabolism and shows evidence of positive selection in humans. Nat Genet. 2007;39(10):1261-5.

11. Grenda A, Leońska-Duniec A, Kaczmarczyk M, Ficek K, Król P, Cięszczyk P, et al. Interaction Between ACE I/D and ACTN3 R557X Polymorphisms in Polish Competitive Swimmers. J Hum Kinet. 2014;10(42):127-36.

12. Ben-Zaken S, Eliakim A, Nemet D, Rabinovich M, Kassem E, MeckelY. ACTN3 Polymorphism: Comparison Between Elite Swimmers and Runners. Sports Med Open. 2015;1(1):13.
13. Trevilatto PC, Line SR. Use of buccal epithelial cells for PCR amplification of large DNA fragments. J Forensic Odontostomatol. 2000;18(1):6-9.

14. Mills $\mathrm{M}$, Yang $\mathrm{N}$, Weinberger $\mathrm{R}$, Vander Woude DL, Beggs AH, Easteal S, et al. Differential expression of the actin-binding proteins, alphaactinin-2 and -3 , in different species: implications for the evolution of functional redundancy. Hum Mol Genet. 2001;1(13):1335-46.

15. 15. Shang X, Huang C, Chang Q, Zhang L, Huang T. Association between the ACTN3 R577X polymorphism and female endurance athletes in China. Int J Sports Med. 2010;31(12):913-6.

16. BelliT, Crisp AH, Verlengia R. Greater muscle damage in athletes with ACTN3 R577X (RS1815739) gene polymorphism after an ultra-endurance race: a pilot study. Biol Sport. 2017;34(2):105-10.

17. Herbert AJ, Williams AG, Lockey SJ, Erskine RM, Heffernan SM, Pedlar CR, et al. P-41 ACTN3 R577x genotype is not associated with elite european caucasian marathon performance. $\mathrm{Br} J$ Sports Med. 2016;50(Suppl 1):A53-4.

18. Coelho DB, Pimenta EM, Rosse IC, de Castro BM, Becker LK, de Oliveira EC. Evidence for a Role of ACTN3 R577X Polymorphism in Football Player's Career Progression. Int J Sports Med. 2018;39(14):1088-93.

19. Druzhevskaya AM, Ahmetov II, Astratenkova IV, Rogozkin VA. Association of the ACTN3 R577X polymor phism with power athlete status in Russians. Eur J Appl Physiol. 2008;103(6):631-4.

20. Gómez-Gallego F, Santiago C, González-Freire M, Muniesa CA, Fernández Del Valle MF, Foster C, et al. Endurance performance: genes or gene combinations? Int J Sports Med. 2009;30(1):66-72.

21. Lucia A, Gómez-Gallego F, Santiago C, Bandrés F, Earnest C, Rabadán M, et al. ACTN3 genotype in professional endurance cyclists. Int J Sports Med. 2006;27(11):880-4.

22. Muniesa CA, González-Freire M, Santiago C, Lao Jl, Buxens A, Rubio JC, et al. World-class performance in lightweight rowing: is it genetically influenced? A comparison with cyclists, runners and non-athletes. Br J Sports Med. 2010;44(12):898-01.

23. Yvert T, Miyamoto-Mikami E, Murakami H, Miyachi M, Kawahara T, Fuku N. Lack of replication of associations between multiple genetic polymorphisms and endurance athlete status in Japanese population. Physiol Reports. 2016;4(20):e13003.

24. Yang R, Shen X, Wang Y, Voisin S, Cai G, Fu Y, et al. ACTN3 R577X Gene Variant Is Associated With MuscleRelated Phenotypes in Elite Chinese Sprint/Power Athletes. J Strength Cond Res. 2017;31(4):1107-15 